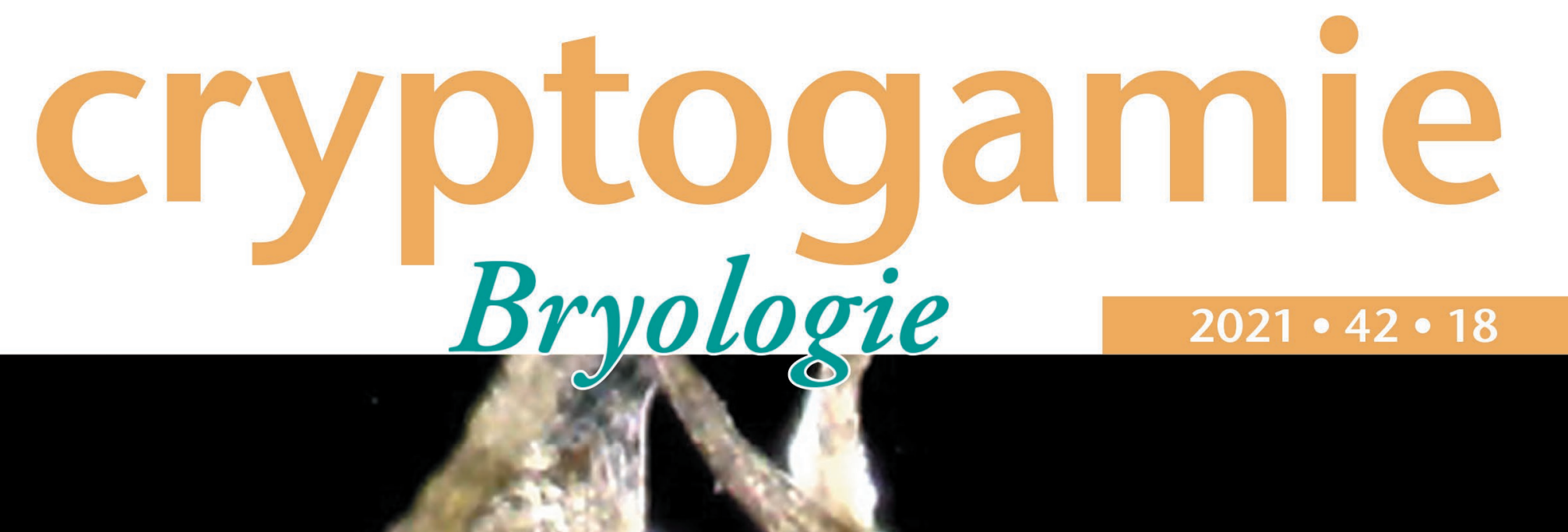

On the symabymization of Acaulon longifolium Herrnst \& Heyn with Acaulon fontiquerianum Casas \& Sérgio (Pottiaceae)

Dror MELAMED, José Gabriel SEGARRA-MORAGUES. Felisa PUCHE, César A. GARCIA \& Cecília SÉRGIÓ 
Directeur de la publication / Publication diREctor: Bruno David,

Président du Muséum national d'Histoire naturelle

RÉDACTEUR EN CHEF / EDITOR-IN-CHIEF: Denis LAMY

ASSISTANTE DE RÉDACTION / ASSISTANT EDITOR: Marianne SALAÜN (bryo@cryptogamie.com)

MISE EN PAGE / PAGE LAYOUT: Marianne SALAÜN

RÉdACTEURS ASSOCIÉS / ASSOCIATE EDITORS

Biologie moléculaire et phylogénie / Molecular biology and phylogeny

Bernard GOFFINET

Department of Ecology and Evolutionary Biology, University of Connecticut (United States)

Mousses d'Europe / European mosses

Isabel DRAPER

Centro de Investigación en Biodiversidad y Cambio Global (CIBC-UAM), Universidad Autónoma de Madrid (Spain)

Francisco LARA GARCÍA

Centro de Investigación en Biodiversidad y Cambio Global (CIBC-UAM), Universidad Autónoma de Madrid (Spain)

Mousses d'Afrique et d'Antarctique / African and Antarctic mosses

Rysiek OCHYRA

Laboratory of Bryology, Institute of Botany, Polish Academy of Sciences, Krakow (Pologne)

Bryophytes d'Asie / Asian bryophytes

Rui-Liang ZHU

School of Life Science, East China Normal University, Shanghai (China)

Bioindication / Biomonitoring

Franck-Olivier DENAYER

Faculté des Sciences Pharmaceutiques et Biologiques de Lille, Laboratoire de Botanique et de Cryptogamie, Lille (France)

Écologie des bryophytes / Ecology of bryophyte

Nagore GARCÍA MEDINA

Department of Biology (Botany), and Centro de Investigación en Biodiversidad y Cambio Global (CIBC-UAM), Universidad Autónoma de Madrid (Spain)

COUVERTURE / COVER:

Extraits d'éléments de la Figure 1 / Extracts of the Figure 1

Cryptogamie, Bryologie est indexé dans / Cryptogamie, Bryologie is indexed in:

- Biological Abstracts

- Current Contents

- Science Citation Index

- Publications bibliographiques du CNRS (Pascal).

Cryptogamie, Bryologie est distribué en version électronique par / Cryptogamie, Bryologie is distributed electronically by:

- BioOne ${ }^{\circledR}$ (http://www.bioone.org)

Cryptogamie, Bryologie est une revue en flux continu publiée par les Publications scientifiques du Muséum, Paris Cryptogamie, Bryologie is a fast track journal published by the Museum Science Press, Paris

Les Publications scientifiques du Muséum publient aussi/ The Museum Science Press also publish: Adansonia, Geodiversitas, Zoosystema, Anthropozoologica, European Journal of Taxonomy, Naturae, Comptes Rendus Palevol, Cryptogamie sous-sections Algologie, Mycologie.

Diffusion - Publications scientifiques Muséum national d'Histoire naturelle

CP 41 - 57 rue Cuvier F-75231 Paris cedex 05 (France)

Tél. : 33 (0)1407948 05 / Fax: 33 (0)1 40793840

diff.pub@mnhn.fr / http://sciencepress.mnhn.fr

(C) Publications scientifiques du Muséum national d'Histoire naturelle, Paris, 2021

ISSN (imprimé / print): 1290-0796 / ISSN (électronique / electronic): 1776-0992 


\title{
On the synonymization of Acaulon longifolium Herrnst. \& Heyn with Acaulon fontiquerianum Casas \& Sérgio (Pottiaceae)
}

\author{
Dror MELAMED \\ 39 Shmuel Tamir St., Tel-Aviv 6963720 (Israel) \\ José Gabriel SEGARRA-MORAGUES \\ Felisa PUCHE \\ Departamento de Botánica y Geología, Facultad de Ciencias Biológicas, \\ Universitat de València. C/ Dr. Moliner s/n, E-46100, Burjassot, Valencia (Spain) \\ j.gabriel.segarra@uv.es (corresponding author) \\ César A. GARCIA \\ Cecília SÉRGIO \\ Universidade de Lisboa, Museu Nacional de História Natural e da Ciência/ \\ CE3C-Centre for Ecology, Evolution and Environmental Changes, \\ Rua da Escola Politécnica, 58, 1250-102 Lisboa (Portugal)
}

Submitted on 4 January 2021 | Accepted on 30 September 2021 | Published on 8 December 2021

KEY WORDS

Endemic species,

Mediterranean, morphology,
mosses,

scanning electron microscopy,

threatened species.
Melamed D., Segarra-Moragues J. G., Puche F., Garcia C. A. \& Sérgio C. 2021. - On the synonymization of Acaulon longifolium Herrnst. \& Heyn with Acaulon fontiquerianum Casas \& Sérgio (Pottiaceae). Cryptogamie, Bryologie 42 (18): 239-248. https://doi.org/10.5252/cryptogamie-bryologie2021v42a18. http://cryptogamie.com/bryologie/42/18

\section{ABSTRACT}

During bryological work conducted in the Sharon plane region (Israel), a colony of Acaulon Müll. Hal. was discovered. The plants showed morphological affinities both to A. longifolium Herrnst. \& Heyn and $A$. fontiquerianum Casas \& Sérgio depending on the floras used for their identification which challenged their recognition as separate species. In order to solve this taxonomic dilemma, we conducted a detailed morphological characterization of the two species based on representative samples. The micromorphological study of vegetative, sporophytic and spore traits revealed the large overlap of range values between both species. Both species showed the characteristic combination of morphological characters, including the broadly incurved leaves with smooth cells and the 4-6 rows of inflated cells on the adaxial surface of nerve. Spore micromorphology revealed the same ornamentation pattern and the presence of 1-2 lamellar glomeruli on spore surface. Multivariate and ordination analyses based on quantitative traits did not reveal a significant separation among samples of the two species, thus opposing their recognition as separate species. As A. fontiquerianum has priority over $A$. longifolium, the latter is thus subsumed in the synonymy of $A$. fontiquerianum. The addition of new chorological data and amended taxonomy reveals that $A$. fontiquerianum has a distribution area extending from the Canary Islands to the eastern Mediterranean basin. However, the scattered pattern suggests its known distribution is largely incomplete because of the tiny size of the plants and their ephemeral nature. 


\author{
MOTS CLÉS \\ Espèce endémique, \\ Méditerranée, \\ morphologie, \\ mousses, \\ microscopie électronique \\ à balayage, \\ espèces menacées.
}

\begin{abstract}
RÉSUMÉ
Sur la synonymisation de Acaulon longifolium Herrnst. \& Heyn avec Acaulon fontiquerianum Casas \& Sérgio (Pottiaceae).

Lors de travaux bryologiques menés dans la région de Sharon plane (Israel), une colonie d'Acaulon Müll. Hal. a été découverte. Les plantes ont montré des affinités morphologiques à la fois avec $A$. longifolium Herrnst. \& Heyn et $A$. fontiquerianum Casas \& Sérgio en fonction des flores utilisées pour leur identification, ce qui a contesté leur reconnaissance en tant qu'espèce distincte. Afin de résoudre cette énigme taxonomique, nous avons effectué une caractérisation morphologique détaillée des deux espèces sur la base d'échantillons représentatifs. L'étude micromorphologique des traits végétatifs, des sporophytes et des spores a révélé un grand chevauchement des gammes de valeur entre les deux espèces. Celles-ci ont montré une combinaison de caractères morphologiques, dont les feuilles largement incurvées avec des cellules lisses et les 4-6 rangées de cellules enflées sur la surface adaxiale de la nervure. La micromorphologie des spores a révélé le même modèle d'ornementation et la présence de 1-2 glomérules lamellaires sur la surface des spores. Les analyses multivariées et d'ordination basées sur des traits quantitatifs n'ont pas révélé de séparation significative entre les échantillons des deux espèces, s'opposant ainsi à leur reconnaissance en tant qu' espèces distinctes. Comme $A$. fontiquerianum a la priorité sur $A$. longifolium, ce dernier est donc considéré comme synonyme d'A. fontiquerianum. L'ajout de nouvelles données chorologiques et d'une taxonomie modifiée montre qu'A. fontiquerianum a une surface de répartition s'étendant des îles Canaries au bassin méditerranéen oriental. Cependant, le modèle dispersé suggère que sa distribution est largement incomplète en raison de la petite taille des plantes et de leur nature éphémère.
\end{abstract}

\section{INTRODUCTION}

Acaulon Müll. Hal. is a taxonomically challenging genus of the Pottiaceae whose representatives are rarely reported. Species of Acaulon inhabit open bare, often disturbed, soil in seasonally wet habitats that remain frequently unexplored but where they can be locally abundant (Sérgio et al. 1993). However, they are comparatively less collected because of the tiny size of the plants and their ephemeral life cycle (Kirmaci \& Erdağ 2014).

Despite its global rarity, the genus Acaulon is distributed in all continents except Antarctica, with much of its diversity being represented in areas of Mediterranean-type climate of Australia, northern and southern Africa, North America and Europe (Stone 1989; Sérgio et al. 1993). It is widespread in the Mediterranean region, where it is represented by eight species, six of which have been reported from Europe (Ros et al. 2013; Hodgetts et al. 2020). Two species have been described comparatively more recently, A. fontiquerianum Casas \& Sérgio (Casas \& Sérgio 1990) and A. longifolium Herrnst. \& Heyn (Herrnstadt \& Heyn 1999). Acaulon fontiquerianum was described from mainland Spain, where most of its known populations occur (Brugués et al. 2018). Despite its rarity it has been reported from scattered localities in six Mediterranean countries (Ros et al. 2013; Hodgetts \& Lockhart 2020). On the other hand, A. longifolium has been less often reported (Herrnstadt et al. 2005) and is considered endemic to Israel. These two species share the presence of enlarged, swollen cells over the adaxial surface of the nerve, a distinctive trait that separates them from all other Mediterranean species and one that is also uncommon in the whole genus (A. recurvatum Magill, a third species with papillose cells, is endemic to South Africa, Magill 1981). This trait suggests a close morphologi- cal relationship or even conspecificity of $A$. fontiquerianum and A. longifolium. Unfortunately, although the former was described almost a decade earlier, $A$. fontiquerianum was not compared to A. longifolium in the description of the later (Herrnstadt \& Heyn 1999). In the original description, it was compared only to three other Mediterranean Acaulon which do not show inflated cells on the adaxial part of the nerve and thus interpreted as a new species. Subsequent studies did not address the potential similarity of these two species (Herrnstadt et al. 2005).

During bryological work conducted in the Sharon plane region (Central-Western Israel), a colony of Acaulon plants was found. Upon microscopic examination, and based on the local flora, the plants presented characters which suggested they belonged to A. longifolium (Herrnstadt et al. 2005). However, consultation of other Mediterranean floras keyed the plants to A. fontiquerianum. This conflict raised reservations about the taxonomic distinction of this species pair. Thus, the aim of this study is to contribute to a better understanding of the taxonomical relationship between $A$. longifolium and A. fontiquerianum based on a thorough study of morphological traits of representative samples.

\section{MATERIAL AND METHODS}

\section{SAMPLED MATERIALS}

Plant materials used in this study consisted of six herbarium vouchers of Acaulon longifolium and ten of A. fontiquerianum, obtained from the Hebrew University of Jerusalem herbarium (HUJ, five vouchers), Museu Nacional de História Natural, Universidade de Lisboa herbarium (LISU, six vouchers), and 
VAL-Briof (five vouchers), as well as fresh field collections. The herbarium material included type specimens of Acaulon fontiquerianum (LISU 153741) and A. longifolium (HUJ 900406, 900408).

Light AND SCANNing EleCtron Microscopy analyses Measurements of vegetative and spore characters were taken using the interactive measurement module of Leica Application Suite (LAS) v. 3.8 (Leica microsystems, Barcelona, Spain) calibrated to the nearest $0.01 \mu \mathrm{m}$ on digital images. All measurements were taken through a DMLB 100S light microscope (Leica). A DFC425 digital camera (Leica) was used for producing high resolution images. For each population, 10 individuals were measured for all 11 qualitative and 18 quantitative traits considered (Table 1). Quantitative morphological traits were scored from a total of five populations ( $N=50$ plants) of $A$. fontiquerianum (LISU 269143, VAL-Briof. 7456, 11274, 11873 and 11874), and from three populations ( $N=30$ plants) of A. longifolium (HUJ 900405 , 900406 and VAL-Briof. 12140).

Scanning Electron Microscopy (SEM) was used to study spore micromorphology. For this purpose, mature spores were mounted directly on stubs using double-sided adhesive tape and coated with gold/palladium in a BIORAD SC-500 ion sputtering coater. Morphological observations were carried out in a Hitachi S-4800 field emission scanning electron microscope (SEM) at the University of Valencia (SCSIE-UV), using an accelerating voltage of $10 \mathrm{Kv}$. Nomenclature of spore characters follows Casas et al. (1990).

\section{STATISTICAL ANALYSES}

Statistical analyses were aimed at revealing whether morphological variation was consistent with the two currently recognized species of Acaulon and if so, at identifying the most informative set of morphological characters for their differentiation. Simple statistical descriptors of the within- and between-species morphological diversity (mean, range) were calculated for all measured characters (Table 1). Quantitative gametophytic, sporophytic and spore traits were further used for producing Factorial Correspondence Analyses (FCA) which were carried out on an individual-variable basis in order to estimate the contribution of the different quantitative traits scored to the morphological differentiation within and among species. Two dimensional plots resulting from the representation of the individual sample scores of two regression factors were constructed. All statistical analyses were conducted using SPSS v. 26.0.

\section{RESULTS}

The collected materials were fertile and allowed a full morphological characterisation of the new Israeli population of Acaulon (Figs 1, 2A-C). According to the morphological characters, these plants could be identified either as A. longifolium according to the Israel bryophyte flora (Herrnstadt et al. 2005) or as A. fontiquerianum following bryophyte floras from elsewhere covering the Mediterranean regions (i.e., Guerra et al. 2006).

The measurement of vegetative, sporophytic and spore traits revealed the large overlap of range values between both species (Table 1). The same applied to qualitative traits which all were homomorphous (Table 1). Both species showed broadly incurved leaves with smooth cells with 4-6 rows of inflated cells on the adaxial surface of the nerve (Fig. 1). Spore micromorphology revealed the same ornamentation processes with spore surface densely covered with a mixture of acute baculae and baculae branched distally with dentate-spinose processes (Fig. 2C, E). Both species presented lamellar glomeruli with dentate-spinose margins (Fig. 2A, B, D, F-H).

In the factorial analysis, considering the whole set of 14 quantitative morphological characters, the first and second factorial functions accounted for only $34.85 \%$ of the total variance. The 2D plot showed samples of $A$. fontiquerianum were spread along the $\mathrm{x}$-axis, indicating substantial morphological variation, intermingling with samples of $A$. longifolium in the left side of the plot (Fig. 3). Generally, samples with smaller values for the morphological traits measured clustered on the left side of the plot whereas samples with larger values clustered to the right; however, both extremes of the plot were connected by a large number of intergrading samples (Fig. 3). In the second factorial function (y-axis) samples from both species spread along positive and negative sides of the axis and thus contributed little to the separation of the two species. The combination of the two most informative factorial functions revealed a large overlap area of samples of A. longifolium with A. fontiquerianum (Fig. 3) with no clear separation.

\section{DISCUSSION}

\section{TAXONOMIC IDENTITY OF ACAULON LONGIFOLIUM}

The genus Acaulon has been the subject of some taxonomic studies during the past decades that have enlarged our understanding of its diversity in different areas of the world (Stone 1976, 1988, 1989; Brugués \& Crum 1984; Casas et al. 1986; Casas \& Sérgio 1990). Particular studies have been performed in search of additional spore micromorphological characters to assist the establishment of taxonomic boundaries (i.e., Casas et al. 1990), while others have revealed the insufficient morphological characterization of species since their description, which have led to obscure the distribution area (Sérgio 1992). The most recent addition of an Acaulon species to the Mediterranean bryoflora was made by Herrnstadt \& Heyn (1999) with the description of A. longifolium. This species shows very different morphological traits to the known Israeli species at that time, which in the view of the authors justified its publication as a new species. Notwithstanding, they failed to compare it with A. fontiquerianum, a mostly western Mediterranean species which was described almost a decade earlier (Casas \& Sérgio 1990).

The examination of the morphological variation of quantitative and qualitative traits scored from the gametophyte, sporophyte and spores between A. fontiquerianum and A. longi- 
TABLE 1. - Summary of the morphological characters studied in Acaulon fontiquerianum Casas \& Sérgio and A. longifolium Herrnst. \& Heyn. For quantitative characters, average and range values, in parentheses, are given. *Bibliographic data.

\begin{tabular}{|c|c|c|}
\hline & Acaulon fontiquerianum & Acaulon longifolium \\
\hline Plant length (mm) & $(1.48-) 2.16(-3.0)$ & $(1.6-) 2.05(-2.87)$ \\
\hline \multicolumn{3}{|l|}{ Leaves } \\
\hline $\begin{array}{l}\text { Number per plant } \\
\text { (including small ones) }\end{array}$ & $(6-) 10(-13)$ & $(6-) 8(-12)$ \\
\hline $\begin{array}{l}\text { Shape } \\
\text { Size of larger leaves }(\mathrm{mm})\end{array}$ & $\begin{array}{l}\text { Broadly ovate, concave, widest at middle, not keeled } \\
(1.16-) 1.90(-2.44) \times(0.44-) 0.87(-1.49)\end{array}$ & $\begin{array}{l}\text { Broadly ovate, concave, widest at middle, not keeled } \\
(1.26-) 1.64(-2.03) \times(0.38-) 0.70(-1.00)\end{array}$ \\
\hline \multicolumn{3}{|c|}{ Basal cells } \\
\hline Shape & Longley rectangular to hexagonal & Longley rectangular to hexagonal \\
\hline Size $(\mu \mathrm{m})$ & $(45.79-) 70.70(-108.07) \times(11.87-) 20.19(-34.65)$ & $(46.37-) 69.11(-91.77) \times(11.73-) 19.41(-32.30)$ \\
\hline \multicolumn{3}{|l|}{ Midleaf cells } \\
\hline Shape & Shortly rectangular, rhomboidal to polygonal & Shortly rectangular, rhomboidal to polygonal \\
\hline Size $(\mu \mathrm{m})$ & $(12.56-) 19.77(-34.46) \times(8.65-) 13.32(-21.01)$ & $(13.26-) 23.67(-35.89) \times(11.80-) 16.80(-23.48)$ \\
\hline \multicolumn{3}{|r|}{ ( } \\
\hline Colour & Brownish green to yellowish brown, concolorous to leaf & Brownish green to yellowish brown, concolorous to leaf \\
\hline Length $(\mu \mathrm{m})$ & $(113.18-) 253.43(-406.87)$ & $(116.85-) 203.82(-313.81)$ \\
\hline \multicolumn{3}{|l|}{ Nerve section } \\
\hline Adaxial cells $(\mu \mathrm{m})$ & $(11.27-) 17.04(-23.35) \times(9.67-) 15.67(-25.72)$ & $(11.61-) 17.65(-22.07) \times(11.69-) 16.71(22.71)$ \\
\hline Hydroids & $1-2$, absent in distal part & $1-2$, absent in distal part \\
\hline Sexual condition & Autoicous ${ }^{*}$, rhizoutoicous*, paroicous & Dioicous* \\
\hline \multicolumn{3}{|l|}{ Sporophyte } \\
\hline Calyptra & Campanulate, mitrate & Campanulate, mitrate \\
\hline Seta type & Straight & Straight \\
\hline Seta length $(\mu \mathrm{m})$ & $(85.72-) 189.29(-334.27)$ & $(101.55-) 151.63(-218.15)$ \\
\hline Capsule shape & Subsphaerical to obovoid & Subsphaerical to obovoid \\
\hline Capsule size $(\mu \mathrm{m})$ & $(424.32-) 689.95(-988.02) \times(344.96-) 599.28(-881.75)$ & $(449.29-) 602.07(-808.91) \times(357.62-) 531.76(-693.41)$ \\
\hline \multicolumn{3}{|c|}{ 孚 } \\
\hline Colour & Orange to brownish & Orange to brownish \\
\hline Size $(\mu \mathrm{m})$ & $(19.07-) 23.32(-27.48) \times(15.16-) 20.87(-24.79)$ & $(20.09-) 23.04(-25.69) \times(16.74-) 21.47(-31.06)$ \\
\hline Ornamentation at LM & Granulose & Granulose \\
\hline Ornamentation at SEM & $\begin{array}{l}\text { Baculate, acute and distally branched baculae with } \\
\text { denticulate/spinose processes. 1-2 lamellar spinose- } \\
\text { dentate glomeruli present }\end{array}$ & $\begin{array}{l}\text { Baculate, acute and distally branched baculae with } \\
\text { denticulate/spinose processes. 1-2 lamellar spinose- } \\
\text { dentate glomeruli present }\end{array}$ \\
\hline
\end{tabular}

folium show both extensive overlap of value ranges for quantitative traits measured, and homomorphy for qualitative traits scored (Table 1; Fig. 2). It is noteworthy to indicate that SEM micromorphological analysis of spores also revealed the same ornamentation pattern between $A$. longifolium (Fig. 2A-F) and $A$. fontiquerianum (Fig. 2G-H) and the presence of 1-2 lamellar glomeruli on the spore surface. This latter trait has been consistently observed throughout its distribution range and has been considered diagnostic of $A$. fontiquerianum (Casas \& Sérgio 1990; Casas et al. 1990; Sérgio et al. 1993; Lo Giudice 1995; Cogoni \& Scrugli 2000).

The reproductive system of $A$. fontiquerianum remains unclear, as for most of its range no data have been provided. However, the species has been reported as autoicous (Casas \& Sérgio 1990), rhizaoutoicous (Cano et al. 2012), and has been observed in one Portuguese and one Spanish population as paroicous, whereas $A$. longifolium has been reported as dioicous (Herrnstadt \& Heyn 1999). Lack of availability of suitable material precluded the reassessment of the reproductive system for most of the materials studied, including those of $A$. longifolium. Thus, it remains ambiguous whether previous studies have determined correctly that the species are reproductively polymorphic, or whether this is due to inaccurate assessments of the reproductive system.

Multivariate analyses based on quantitative traits and ordination of samples in a bidimensional space did not reveal a neat separation among samples of the two species (Fig. 3).
The diffuse clustering, even for the more intensively sampled A. fontiquerianum, may indicate a strong effect of environmental variation on quantitative morphological traits. Although both extremes of the distribution ranges have been sampled for this study, thus covering a significant part of the climatic variation of the distribution range of the species, still no clear differentiation was obtained. Therefore, our analyses oppose the recognition of $A$. fontiquerianum and $A$. longifolium as separate species.

As $A$. fontiquerianum was validly described earlier, this name has priority over $A$. longifolium. Therefore, the following synonymy is proposed:

\section{Family PotTIACEAe Hampe Genus Acaulon Müll. Hal.}

\section{Acaulon fontiquerianum Casas \& Sérgio}

Cryptogamie, Bryologie, Lichénologie 11: 61 (1990).

TYPe. - Spain, Hispania, Cabo de Gata (Almería), Umbría del Cambronero, UTM 30SWF77, suelo al borde de Zizyphus lotus, $100 \mathrm{~m}$ a.s.l., C. Casas, 23.III.1972 (holo-, BCB[BCB24529]; iso-, PC[PC0026212], LISU[LISU153741]!, MUB[MUB3649], $\mathrm{BM}[\mathrm{BM} 000867535])$

Acaulon longifolium Herrnst. \& Heyn., Nova Hedwigia 69: 229, (1999) syn. nov. 

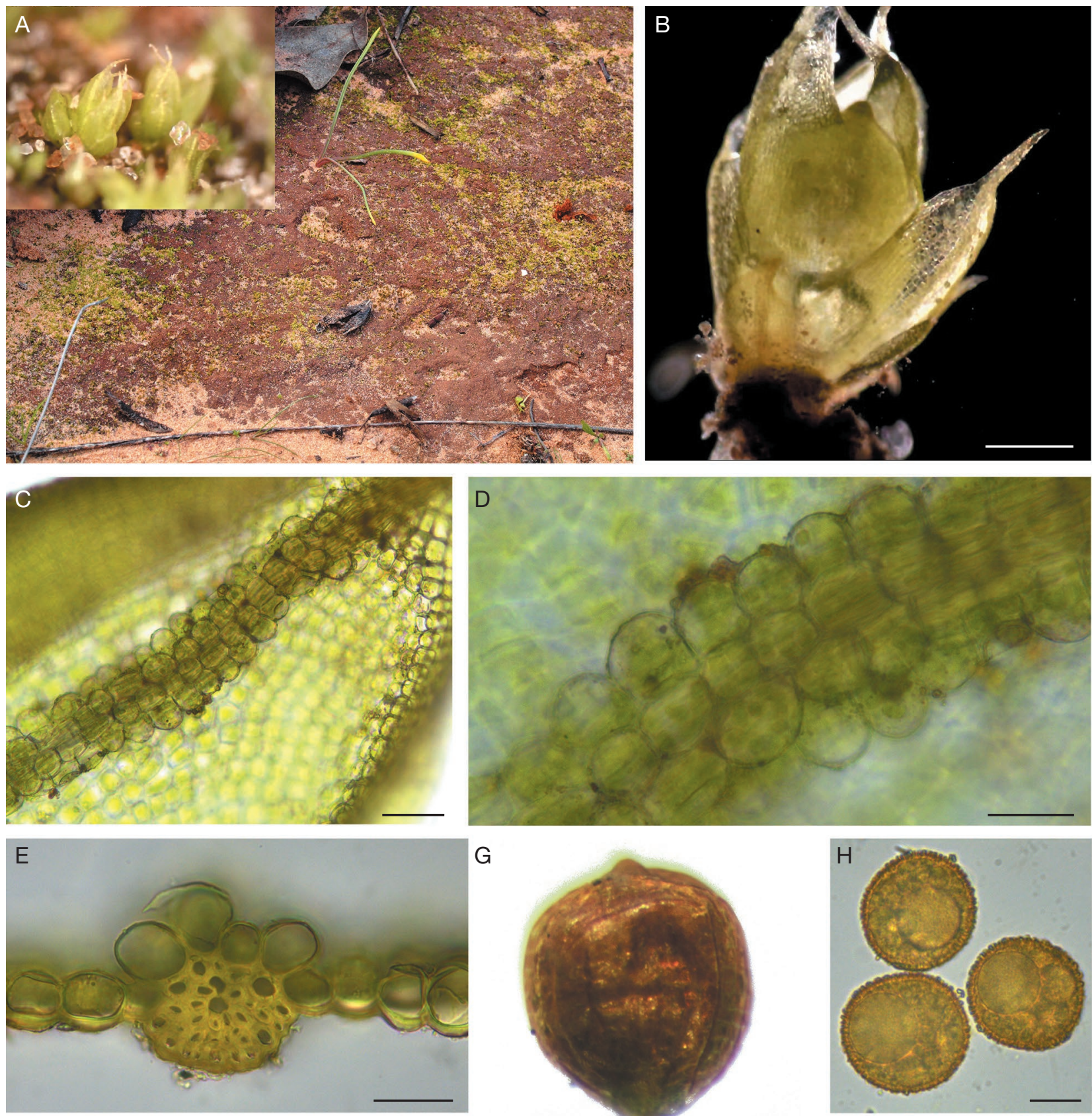

G
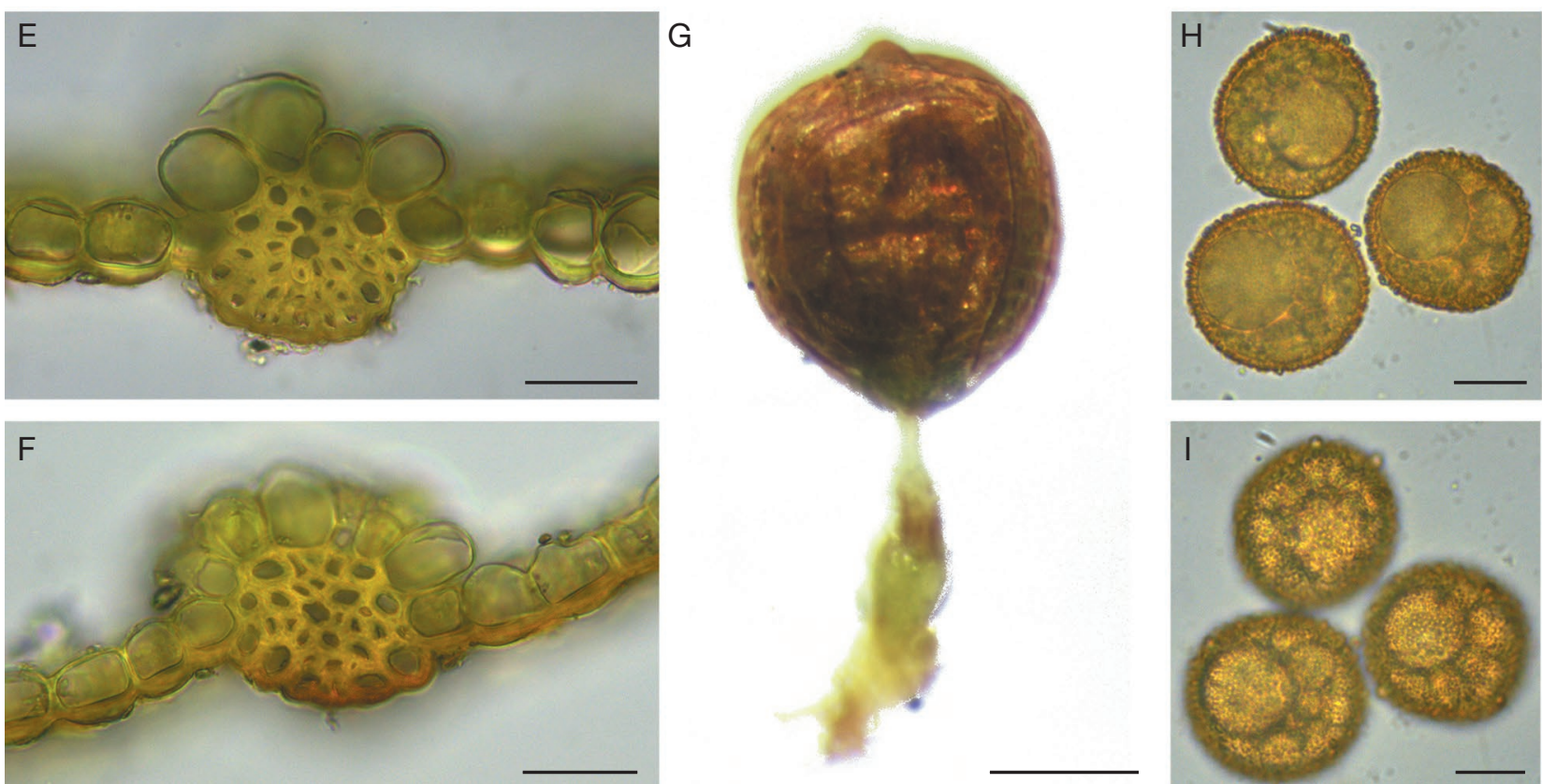

FIG. 1. - Habitat and LM images of Acaulon fontiquerianum Casas \& Sérgio from Israel: A, habitat at llanot Forest, Israel, the inset shows two plants; B, habit of one plant; $\mathbf{C}$, apical part of the adaxial side of a leaf showing the inflated cells over the nerve; $\mathbf{D}$, detail of the four rows of inflated cells over the nerve; $\mathbf{E}$, $\mathbf{F}$, two cross-sections of nerve; G, sporophyte showing the straight seta and the obovoid, shortly apiculate capsule; $\mathbf{H}$, I, spores showing the surface ornamentation (all from VAL-Briof. 12140). Scale bars: B, G, $250 \mu \mathrm{m}$; C, $50 \mu \mathrm{m}$; D-F, $25 \mu \mathrm{m} ; \mathrm{H}, \mathrm{I}, 10 \mu \mathrm{m}$. 
Type. - Sharon Plain, Pardess Hanna, Leg. Tuvia Kushnir, 21.III.1943 (holo-, HUJ[HUJ900407]; iso-, HUJ[HUJ900406]! dupl. VAL.Briof. 12136, HUJ[HUJ900408]! dupl. VAL-Briof. 12406!)

Materials StUdied (* new records). - Israel. Pardes Hanna, in shade of Thymelaea hirsuta, 21.III.1943, T. Kushnir 117, formerly det. by Nachtmony as Acaulon muticum var. cuspidatum. Type locality, same collection of type. (HUJ[HUJ900406], dupl. VAL-Briof.12136, isotype of $A$. longifolium); ibidem, on sandy loam, 21.III.1943, T. Kushnir 214. Type locality, same collection of type. (HUJ[HUJ900408], dupl. VAL-Briof. 12406, isotype of A. longifolium); Philistean plain, Savyon, on partly exposed sandy loam, 15.II.1992, Herrnstadt s.n. (HUJ[HUJ900405], dupl. VALBriof. 12137); ibidem, on sandy loam, partly exposed, 15.II.1992, Herrnstadt s.n. (HUJ[HUJ903667], dupl. VAL-Briof. 12.407); ibidem, on partly exposed sandy loam, 15.II.1992, Herrnstadt s.n. (HUJ[HUJ903663], dupl. VAL-Briof. 12408); *Sharon district, Ilanot Forest, on exposed sandy soil, 28.I.2020, D. Melamed s.n. (VAL-Briof. 12140).

Portugal. *Algarve, Cabo de São Vicente, 50-70 m, 29SNA004973, III.1984, C. Sérgio, M. Brugués, R. M. Cros, (LISU 154915 sub. A. mediterraneum); *Alto Alentejo, Campo Maior, Adega Mayor, 250 m, 29SPD647241, no solo da base de Olea, 13.IV.2019, C. Sérgio 16841 (LISU 269141); *Estremadura, Setúbal, Alcochete, pr. Praia dos Moinhos, 3 m, 29SNC022886, solo de vegetação rasteira, halófita, arenoso e aluvião, ass. Pottia sp. Bryum spp., Dicranella sp., 01.I.2020, C. Sérgio 17180 (LISU 269142); * ibidem, Serra da Arrábida, Vila Nogueira de Azeitão, Casais de Portela, 140 m. 38 29'35.98”N, 902'23.22”W, no caminho e solo no prado semi-natural junto à estrada, ass. Microbryum sp. e Dicranella howei, 25.I.2020, C. Sérgio 17204 (LISU 269143 , dupl. VAL-Briof. 11875); *Ribatejo, Santarém, Caneiras, 19 m, $39.20135^{\circ} \mathrm{W} 8.68425$, in sedimentary soil, open grassland with natural vegetation, associated to Bryum capillare, Riccia sorocarpa, Barbula convoluta, Pleurochaete squarrosa, 05.I.2020, C. Garcia s.n. (LISU 269140).

Spain. Almería, Cabo de Gata, Umbría del Cambronero, $100 \mathrm{~m}$, 30SWF77, suelo al borde de Zizyphus lotus, 23.III.1972, C. Casas (LISU 153741, isotype of A. fontiquerianum). Valencia, Estivella, Puntal de l'Abella, $560 \mathrm{~m}, 39^{\circ} 41^{\prime} 42.41^{\prime \prime} \mathrm{N}, 0^{\circ} 22^{\prime} 57.41$ 'W, on sandy soil, 01.II.2019, J. G. Segarra Moragues \& F Puche s.n. (VAL-Briof. 11873); ibidem, Albalat dels Tarongers, Cerro del Cavall, $200 \mathrm{~m}$, $39^{\circ} 38^{\prime} 49.23^{\prime \prime} \mathrm{N}, 0^{\circ} 21^{\prime} 56.62^{\prime \prime} \mathrm{W}$, on sandy soil, 26.I.2017, J. G. Segarra Moragues \& F. Puche s.n. (VAL-Briof. 11874); ibidem, Marines Viejo, matorral y campos de algarrobos junto al rio, $410 \mathrm{~m}$, $39^{\circ} 44^{\prime} 12.31$ ”N, 0³1'59.27”W, on soil, 18.II.2015, J. G. Segarra Moragues s.n. (VAL-Briof. 11274); Valencia, Sagunto, Monte Picayo, $300 \mathrm{~m}, 39^{\circ} 38^{\prime} 29.13^{\prime \prime} \mathrm{N}, 0^{\circ} 19^{\prime} 10.38^{\prime \prime} \mathrm{W}$, on sandy soil, 22.III.2007, F. Puche s.n. (VAL-Briof. 7456).

\section{DESCRIPTION}

An updated description of $A$. fontiquerianum, integrating the morphological variation from $A$. longifolium specimens studied is presented here:

Plants gregarious, bulbiform, light green becoming light brown with age, to $3.0 \mathrm{~mm}$ high including the leaf aristae; leaves 6-13 per plant, imbricate, incurved, oblong-ovate, concave, $(1.2-) 1.8(-2.4) \times(0 .-) 0.8(-1.5) \mathrm{mm}$, outher leaves smaller, margins entire, recurved near the apex; leaf apex acute. Nerve excurrent in a concolorous, flexuose arista (113.2-)234.8(-406.9) $\mu \mathrm{m}$ long, in cross section with abaxial stereids in 2-3 rows; euricists absent, 1-2 hydroids sometimes present; adaxial surface of the nerve with (2-)4(-5) rows of smooth, inflated, (11.3-)17.3(-28.1) × (9.7-)16.1(-25.7) $\mu \mathrm{m}$, cells, with cell walls thinner than those of cells from lamina.
Cells of lamina smooth, in cross-section with abaxial walls thicker than adaxial ones; basal cells rectangular (45.8-)70.1 $(-108.1) \times(11.7-) 19.9(-32.7) \mu \mathrm{m}$; median cells, rectangular, subquadrate, polygonal to rhomboidal, (12.6-)21.2(-35.9) $\times$ (8.7-) $14.6(-23.5) \mu \mathrm{m}$.

Paroicous, dioicous, autoicous or rhizautoicous. Seta straight, (85.7-)175.2(-334.3) $\mu \mathrm{m}$. Capsule brown, subspherical to obovoid, cleistocarpous, (424.3-)657.0(-988.0) $\times$ (345.0-)574.0(-881.75) $\mu \mathrm{m}$, shortly apiculate. Calyptra conical, mitrate, to $634.7 \times 343.7 \mu \mathrm{m}$. Spores orange to brownish, rounded in shape, (19.1-)23.2(-27.5) $\times(15.2-)$ $21.1(-31.1) \mu \mathrm{m}$, finely granulose at LM. Spore ornamentation at SEM densely baculate, baculae acute to brancheddentate distally; spores with 1-2 lamellar glomeruli with dentate-spinose margins.

\section{Habitat, ECOlOGY AND Distribution}

Species of Acaulon are common elements of bryophyte communities growing on bare, often disturbed, soil with seasonal fluctuation of soil humidity. In such situations they are usually associated with many other ephemeral Pottiaceae, Bryaceae and Ricciaceae. Throughout its distribution range $A$. fontiquerianum has been reported from a variety of soil types (Sérgio et al. 1993), including volcanic, granitic, sandy and red clay (terra rossa), generally characterized by neutral to acidic $\mathrm{pH}$. It also spans a large altitudinal range from almost sea level (Cogoni \& Scrugli 2000) to $2100 \mathrm{~m}$ a.s.l. (Kirmaci \& Erdağ 2014); however, the majority of the populations occur at low to moderate altitudes $<100-1000$ $\mathrm{m}$ a.s.l., and not far from the sea coast. In Israel, three out of the five locations where this species has been collected occur in areas as low as 45-55 m a.s.l. and at 5-10 km distance from the Mediterranean shore, and one (Jerusalem) at about $700 \mathrm{~m}$ a.s.l (D. Melamed, personal observation). Regarding the new population from the Ilanot Forest, a plantation of Eucalyptus sp., the plants were growing on exposed wet sandy soil, together with Microbryum sp. and Tortula acaulon (With.) R.H. Zander.

Acaulon fontiquerianum has been confirmed previously from five Mediterranean countries (Fig. 4): France, including Corsica (Sérgio et al. 1993), Italian islands of Sardinia (Cogoni \& Scrugli 2000) and Sicily (Lo Giudice 1995); Portugal (Sérgio et al. 1993, 2013, plus five additional populations newly reported in this study), Spain (Casas \& Sérgio 1990; Casas et al. 1990; García-Zamora et al. 1998, 1999; Guerra et al. 2010; Ros \& Werner 2010; SegarraMoragues \& Puche 2016; Brugués et al. 2018), including the Canary Islands (Dirkse et al. 1993) and Turkey (Kirmaci \& Erdağ 2014; Ağcagil et al. 2020). A previous report from Morocco by (Cano et al. 2002) needs confirmation, as it was based on immature specimens - however, the plants show the characteristic inflated cells of $A$. fontiquerianum on the adaxial side of the nerve supporting its possible occurrence in North Africa (Cano et al. 2002). In conclusion, the results from this study, based on the taxonomic reassessment of previous records and a recent collection of $A$. longifolium 

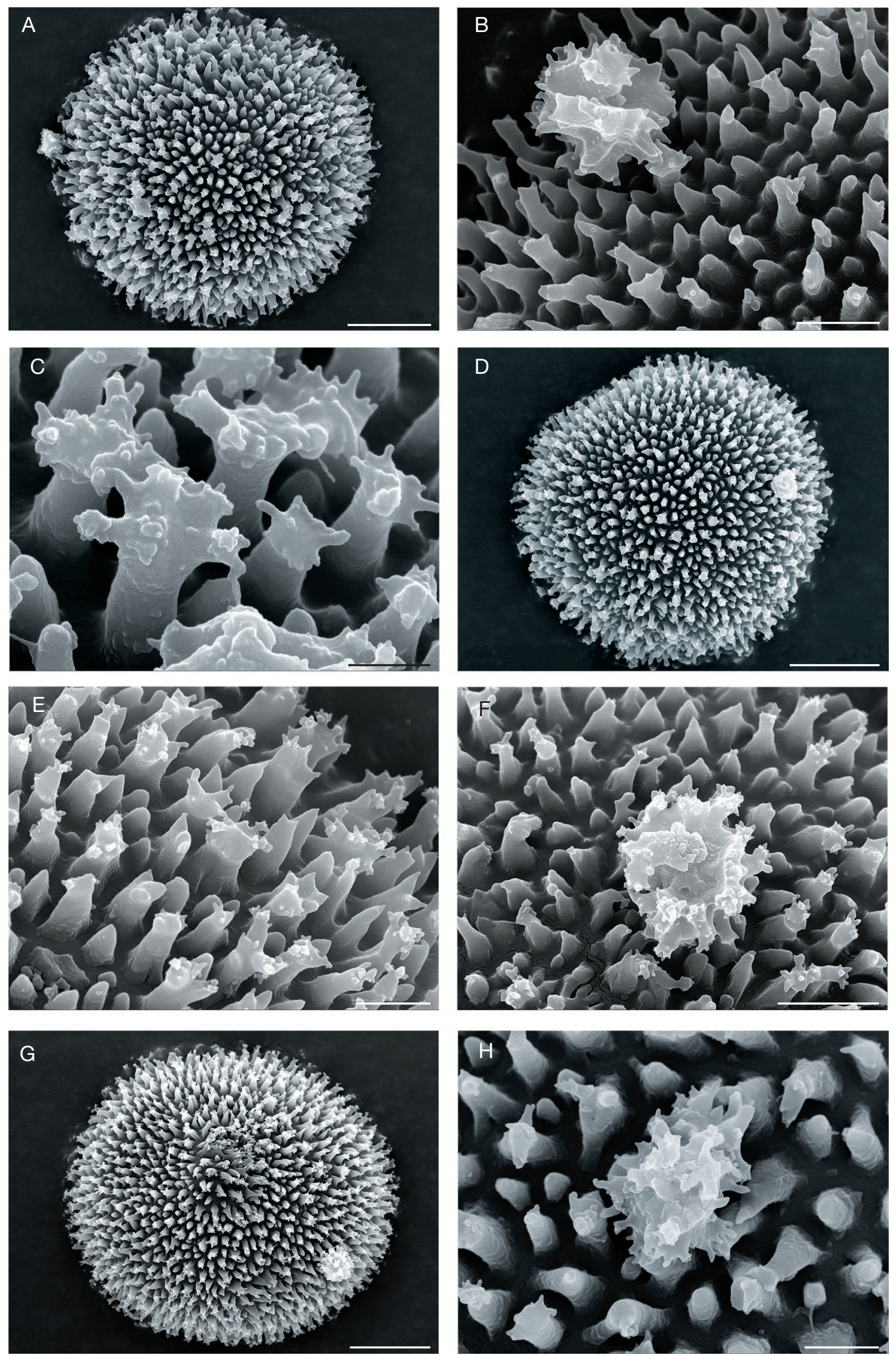

FIG. 2. - SEM images of spores of Acaulon fontiquerianum Casas \& Sérgio. A, D, G, general view; B, F, H, baculae and glomeruli; C, E, detail of branched-dentate baculae apices. (A-C from Israel, VAL-Briof. 12140; D-F from Israel, VAL-Briof. 12136; G from Spain, VAL-Briof. 11873; H from Portugal, LISU 269143, VAL-Briof. 11875). Scale bars: A, $5 \mu \mathrm{m} ; \mathrm{B}, \mathrm{E}, \mathrm{H}, 1 \mu \mathrm{m} ; \mathrm{C}, 0.5 \mu \mathrm{m} ; \mathrm{D}, \mathrm{G}, 6 \mu \mathrm{m} ; \mathrm{F}, 2 \mu \mathrm{m}$. 


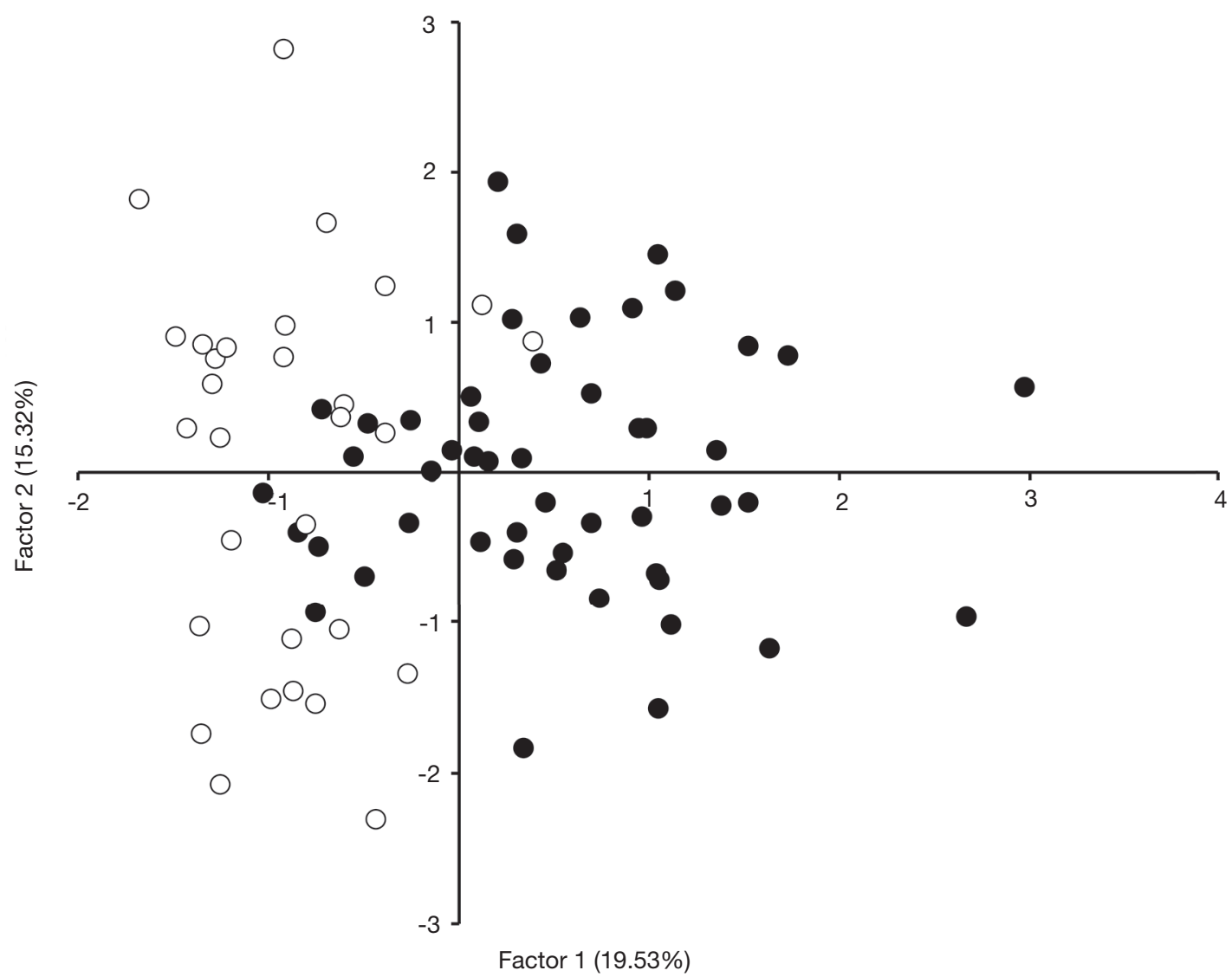

FIG. 3. - Factorial Correspondence Analysis (FCA) of Acaulon fontiquerianum Casas \& Sérgio (black dots) and $A$. longifolium (white dots) samples. The plot represents the space defined by the first $(x$ axis) and second ( $y$ axis) regression factor scores and the percentage of variance explained by each factor is indicated in the corresponding axis of the plot.

(Herrnstadt \& Heyn 1999; Herrnstadt et al. 2005), extend the distribution of $A$. fontequerianum to Israel.

\section{CONSERVATION}

Acaulon fontiquerianum has been assigned to various IUCN threat categories in western Mediterranean countries. It has been assessed as Near Threatened (NT) for Spain (including Canary Islands) by Cano et al. (2012), although its threat category increased to Vulnerable (VU) when only mainland Spain and the Balearic Islands were considered (Brugués \& González-Mancebo 2012; Cano et al. 2012; Albertos et al. 2018). A higher threat category (Critically Endangered, CR) was proposed for Portugal (Sérgio et al. 2013, 2014), whereas no assessment exists for other Mediterranean countries. Two of the Israel populations were collected from areas which are currently urbanized, thus increasing their chances of local extinction. A recent European-wide assessment of threatened bryophytes resulted in $A$. fontequerianum being listed as NT (Hodgetts et al. 2019; Sérgio \& García 2019). Its global distribution pattern clearly shows a higher number of known populations in the western Mediterranean (Fig. 4) including several populations from the Canary Islands, although it is unclear whether the apparent rarity towards the eastern Mediterranean is due to a less intense sampling effort. By contrast, it is apparently absent (or at least very rare) in North Africa (pending confirmation of the report from Cano et al. 2002). This may indicate that knowledge of the actual distribution area is incomplete, an issue exacerbated by the tiny size of the plants and their ephemeral nature in arid habitats. We therefore refrain from proposing changes to the IUCN threat category assigned to this moss until further field explorations are carried out in the eastern Mediterranean area.

\section{Acknowledgements}

We thank Dr Hagar Leschner, collection manager and Dr Neta Manela, scientific manager at the HUJ herbarium for sending duplicates of Israel specimens, M. J. Gil-López for his help in the preparation of the distribution map and Drs R. M. Ros and L. Sáez for helpful comments on an earlier version of the manuscript and R. D. Porley for the revision of the English. SEM images were taken at the Servei Central de Suport a la Investigació Experimental (SCSIE) from the University of Valencia whose technical staff helped with sample preparation for SEM. 


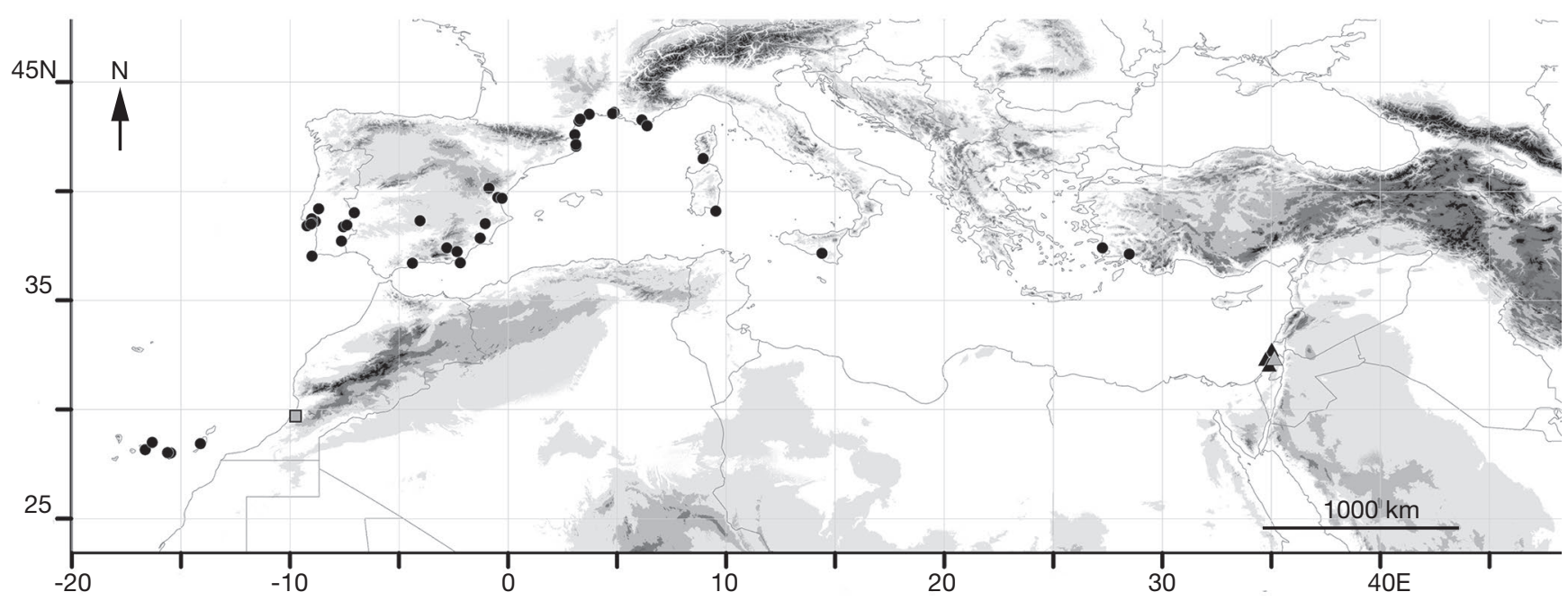

FIG. 4. - Known world distribution of Acaulon fontiquerianum Casas \& Sérgio based on published records and herbarium specimens. Black dots indicate populations initially ascribed to $A$. fontiquerianum; a grey square indicates an unconfirmed Moroccan population of this species. Populations initially adscribed to $A$. longifolium Herrnst. \& Heyn. and the new population are represented with black and grey triangles, respectively. Latitude and longitude numbers are indicated in degrees.

\section{REFERENCES}

AĞCAgil E., Kirmaci M. \& ÖZEnoglu H. 2020. — The bryophyte flora of Samsun Mountain (Aydın/Turkey). Acta Biologica Turcica 33: 193-204.

Albertos B., Garilleti R., Heras P. \& Infante M. 2018. - On the mend of bryophyte conservation in Spain: preparing a proposal for the inclusion of bryophytes in national species protection catalogues. Mediterranean Botany 39: 119-128. https://doi. org/10.5209/MBOT.60070

Brugués M. \& CRUm H. 1984. - Acaulon casasianum a new moss from Spain. Lindbergia 10: 1-3.

Brugués M. \& GonZÁlez-Mancebo J. M. 2012. — Lista Roja de los Briófitos Amenazados de España, in GARILLETI R. \& AlBERTOS B. (coords), Atlas y Libro Rojo de los Briófitos Amenazados de España. Organismo Autónomo Parques Nacionales, Madrid: 26-42 (available at: http://www.uv.es/abraesp) (last accessed 27 July 2021).

Brugués M., Cros R. M., Sérgio C., Cano M. J. \& Guerra J. 2018. - Acaulon fontiquerianum Casas \& Sérgio. Barcelona. Available at: http://briofits.iec.cat (Accessed 17 November 2020).

Cano M. J., Dirkse G., González-Mancebo J. M., Guerra J. \& Patiño J. 2012. - Acaulon fontiquerianum Casas \& Sérgio, in Garilleti R. \& Albertos B. (coords), Atlas y Libro Rojo de los Briófitos Amenazados de España. Organismo Autónomo Parques Nacionales, Madrid: 167-168 (available at: http://www.uv.es/ abraesp) (last accessed 27 July 2021).

Cano M. J., Ros R. M., Gallego M. T., Jiménez J. A. \& Guerra J. 2002. - Contribution to the bryophyte flora of Morocco: the Anti-Atlas catalogue. Cryptogamie, Bryologie 23: 249-262.

CASAS C. \& SÉRGIO C. 1990. - Acaulon fontiquerianum sp. nov. de la Peninsula Ibérica. Cryptogamie, Bryologie, Lichénologie 11:57-61.

Casas C., Sérgio C., Cros R. M. \& Brugués M. 1986. - Acaulon dertosense sp. nov., musgo terrícola de los olivares del Baix Ebre. Anales del Jardín Botánico de Madrid 42: 299-301.

Casas C., Sérgio C., Cros R. M. \& Brugués M. 1990. — Dados sobre el género Acaulon en la Península Ibérica. Cryptogamie, Bryologie et Lichénologie 11: 63-70.

CogOni A. \& SCRUGLI A. 2000. - Acaulon fontiquerianum Casas et Sérgio (Musci, Pottiaceae) new to Sardinia. Cryptogamie, Bryologie 21: 285-288. https://doi.org/10.1016/S1290-0796(00)01044-0
Dirkse G. M., Bouman A. C. \& Losada-Lima A. 1993. - Bryophytes of the Canary Islands, an annotated checklist. Cryptogamie Bryologie Lichénologie 14: 1-47.

García-Zamora P., Ros R. M. \& Guerra J. 1998. - Bryophyte flora of the Sierras de Filabres, Cabrera, Alhamilla and Cabo de Gata (Almería, SE Spain). Journal of Bryology 20: 461-493. https://doi.org/10.1179/jbr.1998.20.2.461

García-Zamora P., Ros R. M. \& Guerra J. 1999. — Briófitos como bioindicadores de calidad botánica en zonas áridas del sudeste Español: Sierras de Filabres, Cabrera, Alhamilla y Cabo de Gata (Almería, España). Acta Botanica Malacitana 24: 113131. https://doi.org/10.24310/abm.v24i0.8522

Guerra J., CANO M. J. \& Ros R. M. (EDS). 2006. — Flora Briofitica Ibérica. Vol. III: Pottiaceae, Encalyptaceae. Sociedad Española de Briología, Universidad de Murcia, Murcia.

Guerra J., Cano M. J., Gallego M. T., Orgaz J. D. \& JiméNEZ J. A. 2010. - Novedades corológicas para la flora briofítica ibérica IV. Anales de Biología 32: 95-99.

Herrnstadt I. \& Heyn C. C. 1999. - Three new taxa of Pottiaceae (Musci) from Israel: Acaulon longifolium, Pottia gemmifera and Barbula ehrenbergii var. gemmipara. Nova Hedwigia 69: 229-235. https://doi.org/10.1127/nova.hedwigia/69/1999/229

Herrnstadt I., Heyn C. C. \& Jovet-Ast S. 2005. - The bryophyte flora of Israel and adjacent regions. Israel Academy of Sciences and Humanities, Jerusalem, Israel, 736 p.

HodgetTs N. G. \& LOCKHART N. 2020. - Checklist and country status of European bryophytes - update 2020. Irish Wildlife Manuals, 123. National Parks and Wildlife Service, Department of Culture, Heritage and the Gaeltacht, Ireland.

Hodgetts N. G., CÁlix M., Englefield E., Fettes N., García Criado M., Patin L., Nieto A., Bergamini A., Bisang I., Baisheva E., Campisi P., Cogoni A., Hallingbäck T., KonSTANTiNOVA N., LOCKHART N., SABOVlJEVIĆ M., SCHNYDER N., Schröck C., Sérgio C., Sim Sim M., Vrba J., Ferreira C. C., afonina O., Blockeel T., Blom H., Caspari S., Gabriel R., Garcia C., Garilleti R., GonZÁlez Mancebo J., Goldberg I., Hedenäs L., Holyoak D., Hugonnot V., Huttunen S., Ignatov M., Ignatova E., Infante M., JuUtinen R., KieBACHER T., KÖCKINGER H., KUČERA J., LÖNNELL N., LÜTH M., Martins A., Maslovsky O., Papp B., Porley R., Rothero G., SÖDERSTRÖM L., ŞTEFANUȚ S., SyRJÄNEN K., UnTEREINER A., VÁNa J., Vanderpoorten A., Vellak K., Aleffi M., Bates J., 
Bell N., Brugués M., Cronberg N., Denyer J., Duckett J., During H. J., Enroth J., Fedosov V., Flatberg K.-I., Ganeva A., Gorski P., GunNarsson U., Hassel K., HespanHOl H., Hill M., Hodd R., Hylander K., IngerpuU N., LAaKaLindberg S., Lara F., MazimpaKa V., MeŽaka A., Müller F., Orgaz J. D., Patiño J., Pilkington S., Puche F., Ros R. M., Rumsey F., Segarra-Moragues J. G., Séneca A., Stebel A., Virtanen R., Weibull H., Wilbraham J. \& Żarnowiec J. 2019. - A Miniature World in Decline: European Red-List of Mosses, Liverworts and Hornworts. Brussels, Belgium: IUCN. https://doi.org/10.2305/IUCN.CH.2019.ERL.2.en

Hodgetts N. G., Söderström L., Blockeel T. L., Caspari S., Ignatov M. S., Konstantinova N. A., Lockhart N., Papp B., Schröck C., Sim-Sim M., Bell D., Bell N. E., Blom H. H., Bruggeman-Nannenga M. A., Brugués M., Enroth, J., Flatberg K. I., Garilleti R., Hedenäs L., Holyoak D. T., Hugonnot V., KariYawasam I., KöCKInger H., KuČERA J., LARA F. \& PORley R. D. 2020. — An annotated checklist of bryophytes of Europe, Macaronesia and Cyprus. Journal of Bryology 42 (1): 1-116. https://doi.org/10.1080/03736687.2 019.1694329

KirmaCi M. \& ERDAĞ A. 2014. - Acaulon fontiquerianum (Pottiaceae), a new species to the bryophyte flora of Turkey and SW Asia. Polish Botanical Journal 59: 229-233. https://doi. org/10.2478/pbj-2014-0028

Lo GiUdice R. 1995. - Acaulon fontiquerianum Casas \& Sérgio (Pottiaceae, Bryophyina), new to the bryoflora of Italy. Flora Mediterranea 5: 69-72.

Magill R. E. 1981. - Flora of southern Africa, Bryophyta part 1 fasc. 1. Botanical Research Institute, Department of Agriculture and Fisheries, South Africa.

Ros R. M., Mazimpaka V., Abou-Salama U., Aleffi M., Blockeel T. L., Brugués M., Cros R. M., Dia M. G., Dirkse G. M., Draper I., El-SAadaWI W., ERdaĞ A., GaneVa A., Gabriel R., GonzÁlez-Mancebo J. M., Granger C., Herrnstadt I., Hugonnot V., Khalil K., KÜrschner H., Losada-Lima A., Luís L., Mifsud S. D., Privitera M., Puglisi M., Sabovljević M., Sérgio C., Shabbara H. M., Sim-Sim M., Sotiaux A., TaC-
CHI R., VAnderpoorten A. \& Werner O. 2013. - Mosses of the Mediterranean, an annotated checklist. Cryptogamie, Bryologie 34: 99-283. https://doi.org/10.7872/cryb.v34.iss2.2013.99

Ros R. M. \& WERNER O. 2010 - Nuevos datos sobre los briófitos de la región de Murcia. Boletín de la Sociedad Española de Briología 34-35: 75-80.

Segarra-Moragues J. G. \& Puche F. 2016. - The bryophyte flora of Sierra Calderona (Valencia and Castellón provinces, eastern Spain). Boletín de la Sociedad Española de Briología 46-47: 11-35

SÉRGIO C. 1992. - Re-evaluation of Acaulon piligerum (De Not.) Limpr. (Pottiaceae) from Sardinia, as a species of a subgenus new to Europe (Alaticosta Stone). Cryptogamie, Bryologie Lichénologie 13: 221-226

Sérgio C., Garcia C. A., Sim-Sim M., Vieira C., Hespanhol H. \& STOW S. 2013. - Atlas e Livro Vermelho dos Briófitos ameaçados de Portugal (Atlas and Red Data Book of Endangered Bryophytes of Portugal). MUHNAC. Documenta. Lisboa, 464 p.

Sérgio C., Garcia C. A., Vieira C., Hespanhol H., Sim-Sim M., Stow S. \& Figueira R. 2014. - Conservation of Portuguese red-listed bryophytes species in Portugal: Promoting a shift in perspective on climate changes, Plant Biosystems 148: 837-850. https://doi.org/10.1080/11263504.2014.949329

SÉrgIO C. \& GARCIA C. A. 2019. - Acaulon fontiquerianum. The IUCN Red List of Threatened Species 2019: e.T84534623A87728817. Downloaded on 18 November 2020.

SÉrgio C., Hébrard J.-P. \& CaSAS C. 1993. - Acaulon fontiquerianum Casas \& Sérgio (Musci, Pottiaceae) nouveau pour la bryoflore du Portugal, de France et de Corse. Orsis 8: 11-19.

STONE I. G. 1976. - Alaticosta, a new subgenus of Acaulon, in Australia. Journal of Bryology 9: 213-217. https://doi.org/10.1179/ jbr.1976.9.2.213

STONE I. G. 1988. - Acaulon granulosum, a new species in the Acaulon muticum complex: a comparison and key to Australian species. Journal of Bryology 15: 257-268. https://doi.org/10.1179/ jbr.1988.15.2.257

Stone I. G. 1989. - Revision of Phascum and Acaulon in Australia. Journal of Bryology 15: 745-777. https://doi.org/10.1179/ jbr.1989.15.4.745 